M.V. Rotermel ${ }^{\mathrm{a}}$, T. I. Krasnenko ${ }^{\mathrm{a}}$, S. A. Petrova ${ }^{b}$, S. G. Titova ${ }^{\mathrm{b}}$

${ }^{a}$ Institute of Solid State Chemistry, Ural Branch of the Russian Academy of Sciences, 91 Pervomayskaya St., Ekaterinburg, 620990, Russian Federation ${ }^{b}$ Institute of Metallurgy,

Ural Branch of the Russian Academy of Sciences, 101Amundsena St., Ekaterinburg, 620016, Russian Federation rotermel@ihim.uran.ru

\title{
Conditions for the formation of a non-autonomous phase at the structural deformation of complex vanadium oxides
}

A new previously unknown effect of a reversible transition from a singlephase system to a heterophase system containing a non-autonomous phase was observed during thermal and chemical deformations of the $\mathrm{Zn}_{2-2 x} \mathrm{Cd}_{2 x} \mathrm{~V}_{2} \mathrm{O}_{7}$ structure. The role of local symmetry in the formation of the non-autonomous phase is shown on the basis of $\mathrm{X}$-ray diffraction studies in situ and a comparative crystal-chemical analysis of the structural deformations of isoform monoclinic solid solutions of zinc and copper pyrovanadates with zero volumetric thermal expansion.

Keywords: non-autonomous phase, volume thermal expansion, $\mathrm{M}_{2} \mathrm{~V}_{2} \mathrm{O}_{7}$

Received: 02.03.2018. Accepted: 10.04.2018. Published: 10.05.2018.

(c) Rotermel M. V., Krasnenko T. I., Petrova S. A., Titova S. G., 2018

\section{Introduction}

The non-autonomous phase is a phase whose existence under a certain thermodynamic conditions is possible only in an ensemble with one or more compounds. Since the introduction of R. Defay in 1961 $[1,2]$, the term of "non-autonomous phase" was used, primarily, in connection with the assumption of a special role of the surface where the concentration of defects is higher than in the volume. To date, non-autonomous phases have been detected as components of various heterophase systems. Thus, considerable attention has been paid in recent years to non-autonomous surface phases in the geological and mineralogical literature, where their roles in the adsorp- tion and segregation of impurities on the surface, or in interphase and intergranular borders, and also in the transfer of matter from high pressure to normal conditions have been established [3-7]. Stabilization of such phase associations is provided by an increase in the total free energy due to the energy of coherent inter-phase boundaries. Changes in the elemental composition of the surface of synthetic single crystals and ceramics due to thermally activated heterosegregation were shown earlier [8]. A supramolecular concept of eutectics that takes into account the interaction of disproportionate substructures and reveals mechanisms of formation of supramo- 
lecular ensembles in boundary layers, i.e. non-autonomous phases, was suggested in a number of works, which studied eutectic alloys in inorganic systems [9]. A "composite effect" resulting in high ionic conductivity was found in several binary systems, and has been used for preparation of electrode materials for the chemical power sources because of the high ionic conductivity of the particles of the nonautonomous phase. The participation of non-autonomous phases in the solid-phase synthesis and sintering of ceramic samples at Tammann temperature due to the melting of the non-autonomous phase on the matrix surface were assumed and thermodynamically justified, as well as participation of the non-autonomous phase in the charge and mass transfer processes was shown [10-16]. We discovered a new, previously unknown effect of a reversible transition from a single-phase system to a heterophase system; the latter, together with the main phase, contains also the non-autonomous phase (NP). Monoclinic $\beta-\mathrm{Zn}_{2-2 x} \mathrm{Cd}_{2 x} \mathrm{~V}_{2} \mathrm{O}_{7}$ solid solutions (space group $\mathrm{C} 2 / \mathrm{m}$ ) contain the non-autonomous phase within the temperature range 20 $735^{\circ} \mathrm{C}$ with the compositional range varied from 2.5 to $50 \mathrm{~mol}$. $\%$ of $\mathrm{Cd}_{2} \mathrm{~V}_{2} \mathrm{O}_{7}$ in amount of several percent (Fig. 1).

\section{Experimental}

Solid solutions in the $\mathrm{Zn}_{2} \mathrm{~V}_{2} \mathrm{O}_{7}$ $\mathrm{Cd}_{2} \mathrm{~V}_{2} \mathrm{O}_{7}$ and $\mathrm{Zn}_{2} \mathrm{~V}_{2} \mathrm{O}_{7}-\mathrm{Cu}_{2} \mathrm{~V}_{2} \mathrm{O}_{7}$ systems were obtained by the ceramic synthesis method. X-ray in situ studies were carried out using a diffractometer SHIMADZU XDR7000 ( $\mathrm{Cu} \mathrm{Ka}$ radiation) in the range of angles $2 \theta$ from $5^{\circ}$ to $120^{\circ}$ with steps
The increase of temperature narrows the region of the heterophase system. High-temperature X-ray diffraction method showed that negative or close to zero volume thermal expansion was observed inside the region where $\beta-\mathrm{Zn}_{2-2 x} \mathrm{Cd}_{2 x} \mathrm{~V}_{2} \mathrm{O}_{7}$ and the non-autonomous phase coexisted. A precise high-temperature and low-temperature in situ X-ray diffraction studies of thermal expansion for a number of monoclinic $\beta-\mathrm{Cu}_{2-2 x} \mathrm{Zn}_{2 x} \mathrm{~V}_{2} \mathrm{O}_{7}(x=0.15$, $0.3,0.4,0.6)$ solid solution samples (space group $C 2 / c$ ) were performed in order to set the conditions for appearance and stabilization of the non-autonomous phase. Although the negative volume thermal expansion over a wide temperatures range was observed, the presence of the nonautonomous phase in the entire region of $\mathrm{Cu}_{2-2 x} \mathrm{Zn}_{2 x} \mathrm{~V}_{2} \mathrm{O}_{7}$ existence was not confirmed (Fig. 1). A comparative analysis of two vanadate systems that contain the solid solutions with identical chemical formula and monoclinic crystal structure, both with the wide range of close to zero and negative volume thermal expansion, allows to propose the structural model for the appearance and stabilization of the non-autonomous phase for the low-symmetric pyrovanadates of divalent metals.

$0.02^{\circ}$, with silicon as an external standard. High-temperature measurements were performed with an Anton Paar TTK-450 attachment. The crystal structure refinement of the powder diffraction data was made using the GSAS software.

\section{Results and discussion}

The changes of unit cell parameters for the solid solutions within the temperature range from the room temperature up to $800^{\circ} \mathrm{C}$ were analyzed (Fig. 2 ) in order to 
establish the relations between the appearance of non-autonomous phase in the $\mathrm{Zn}_{2} \mathrm{~V}_{2} \mathrm{O}_{7}-\mathrm{Cd}_{2} \mathrm{~V}_{2} \mathrm{O}_{7}$ system and the transformations of the matrix phase. Maximum thermal deformations, accompanied by the close to zero volume thermal expansion (for $\beta-\mathrm{Zn}_{1.6} \mathrm{Cd}_{0.4} \mathrm{~V}_{2} \mathrm{O}_{7} \alpha_{V}=-0.08 \times 10^{-5}$ $\left.\mathrm{deg}^{-1}\right)$, were observed within the region of $\beta-\mathrm{Zn}_{2-2 x} \mathrm{Cd}_{2 x} \mathrm{~V}_{2} \mathrm{O}_{7}$ and the non-autonomous phase coexistence. Noticeable expansion of monoclinic solid solution was observed out of the range of stabilization for the nonautonomous phase. Significant changes of the unit cell parameters $a$ and $b$ take place inside the region of heterophase system. The maximal transformation of the monoclinic plane (ac) happens due to the change in the $\beta$ angle, which causes shear deformation at a fixed rotation angle of $\left[\mathrm{VO}_{4}\right]$-tetrahedron; $\mathrm{V}-\mathrm{O}_{\text {bridge }}-\mathrm{V}=180^{\circ}, \mathrm{C2} / \mathrm{m}$ (Fig. 3). Analysis of the changes in the unit cell parameters for the $\beta-\mathrm{Zn}_{2-2 x} \mathrm{Cd}_{2 x} \mathrm{~V}_{2} \mathrm{O}_{7}$ solid solutions indicates the existence of a correlation between the appearance and dis- appearance of the non-autonomous phase and the shear strain intensity with a change

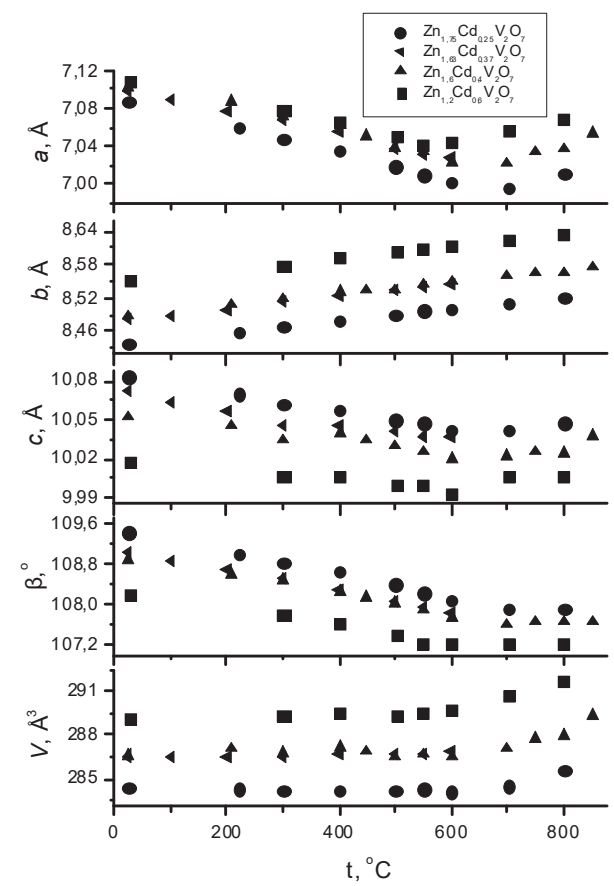

Fig. 2. The unit cells parameters for the $\beta-\mathrm{Zn}_{2-2 x} \mathrm{Cd}_{2 x} \mathrm{~V}_{2} \mathrm{O}_{7}$ solid solutions versus temperature $\beta-\mathrm{Zn}_{2-2 x} \mathrm{Cd}_{2 x} \mathrm{~V}_{2} \mathrm{O}_{7}$

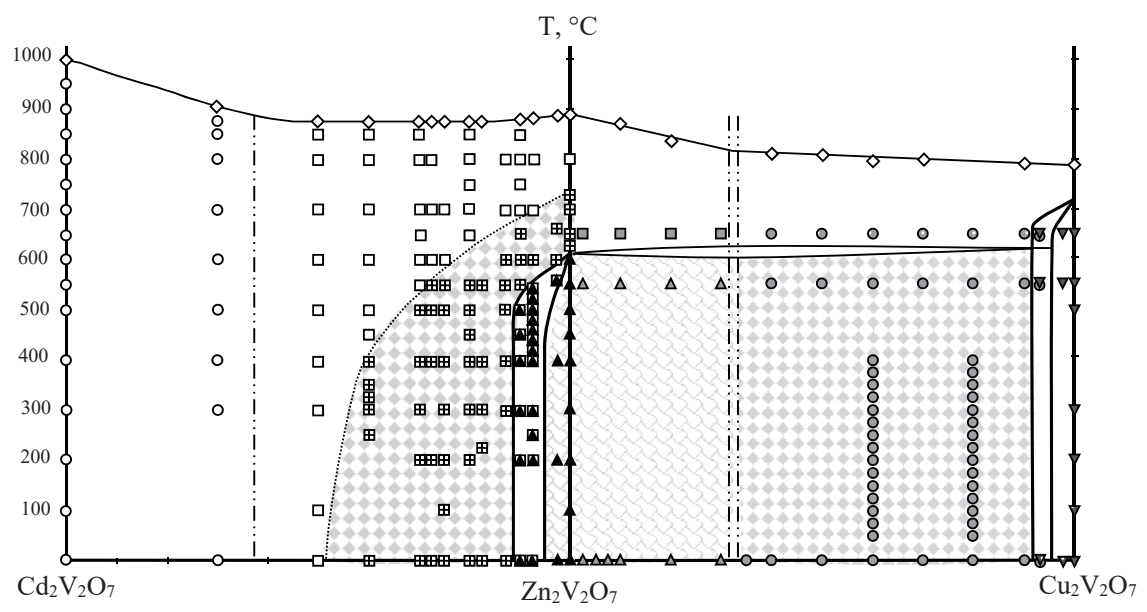

Fig. 1. Phase equilibria in the $\mathrm{Cd}_{2} \mathrm{~V}_{2} \mathrm{O}_{7}-\mathrm{Zn}_{2} \mathrm{~V}_{2} \mathrm{O}_{7}$ and $\mathrm{Zn}_{2} \mathrm{~V}_{2} \mathrm{O}_{7}-\mathrm{Cu}_{2} \mathrm{~V}_{2} \mathrm{O}_{7}$ systems:

O - solid solution $\mathrm{Cd}_{2-2 \mathrm{x}} \mathrm{Zn}_{2 \mathrm{x}} \mathrm{V}_{2} \mathrm{O}_{7}$; $\mathrm{\square}$ - solid solution of $\beta-\mathrm{Zn}_{2-2 \mathrm{x}} \mathrm{Cd}_{2 \mathrm{x}} \mathrm{V}_{2} \mathrm{O}_{7}$;

田 - solid solution $\beta-\mathrm{Zn}_{2-2 \mathrm{x}} \mathrm{Cd}_{2 \mathrm{x}} \mathrm{V}_{2} \mathrm{O}_{7}+\mathrm{NP} ; \boldsymbol{\Delta}$ - solid solution of $\alpha-\mathrm{Zn}_{2-2 \mathrm{x}} \mathrm{Cd}_{2 \mathrm{x}} \mathrm{V}_{2} \mathrm{O}_{7}$;

$\Delta$ - solid solution $\alpha-\mathrm{Zn}_{2-2 \mathrm{x}} \mathrm{Cu}_{2 \mathrm{x}} \mathrm{V}_{2} \mathrm{O}_{7}$; $\mathbf{\square}$ - solid solution of $\beta-\mathrm{Zn}_{2-2 \mathrm{x}} \mathrm{Cu}_{2 \mathrm{x}} \mathrm{V}_{2} \mathrm{O}_{7}$;

- - solid solution $\beta-\mathrm{Cu}_{2-2 \mathrm{x}} \mathrm{Zn}_{2 \mathrm{x}} \mathrm{V}_{2} \mathrm{O}_{7}$; $\bullet-$ solid solution of $\beta^{\prime}-\mathrm{Cu}_{2-2 \mathrm{x}} \mathrm{Zn}_{2 \mathrm{x}} \mathrm{V}_{2} \mathrm{O}_{7}$;

$\boldsymbol{\nabla}$ - solid solution $\alpha-\mathrm{Cu}_{2-2 \mathrm{x}} \mathrm{Zn}_{2 \mathrm{x}} \mathrm{V}_{2} \mathrm{O}_{7} ; \diamond-$ solidus line 
in the monoclinic angle. Significant shear deformations were detected exactly in the region where $\beta-\mathrm{Zn}_{2-2 x} \mathrm{Cd}_{2 x} \mathrm{~V}_{2} \mathrm{O}_{7}$ and nonautonomous phase coexisted; therefore, it can be assumed that the monoclinic plane in this case serves as a substrate generating the non-autonomous phase. An increase in temperature or concentration of dopant cation leads to the disappearance of the

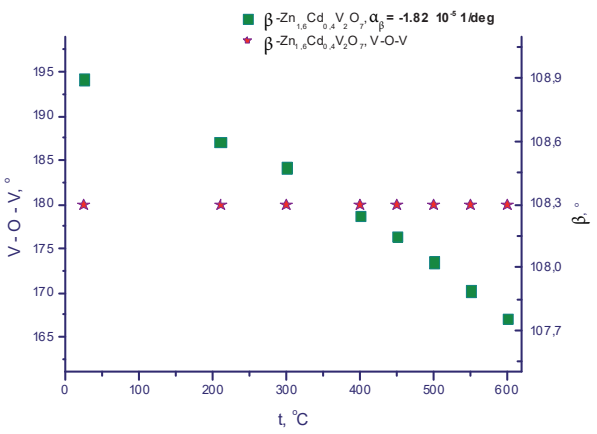

Fig. 3. The monoclinic angle and the rotation angle of $\left[\mathrm{VO}_{4}\right]$-tetrahedron in $\beta-\mathrm{Zn}_{2-2 \mathrm{x}} \mathrm{Cd}_{2 \mathrm{x}} \mathrm{V}_{2} \mathrm{O}_{7}$ vs temperature

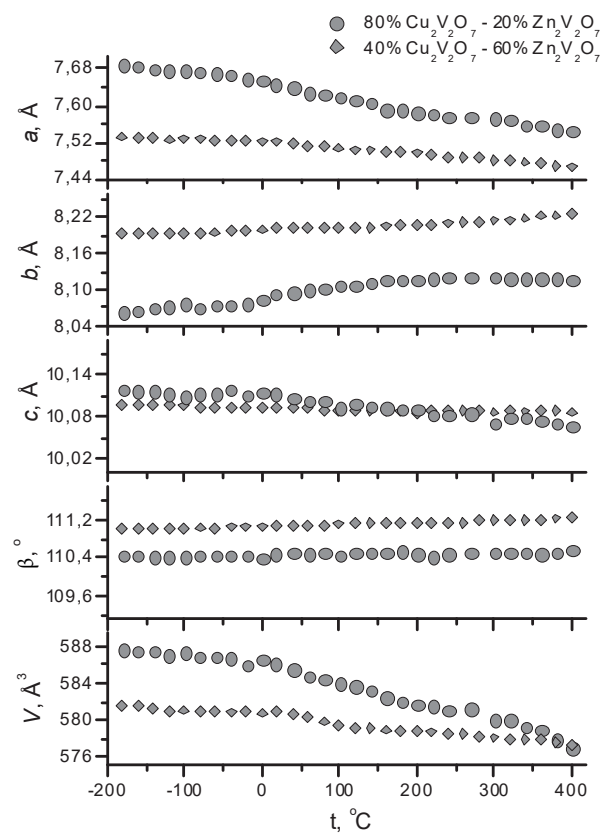

Fig. 4. The unit cells parameters for the $\mathrm{Cu}_{1,6} \mathrm{Zn}_{0,4} \mathrm{~V}_{2} \mathrm{O}_{7}$ and $\mathrm{Cu}_{0,8} \mathrm{Zn}_{1,2} \mathrm{~V}_{2} \mathrm{O}_{7}$ solid solutions vs temperature shear deformation, and at the same time to the disappearance of the non-autonomous phase, as shown in Fig. 1.

Thermal behavior of two representative solid solution samples in the $\mathrm{Zn}_{2} \mathrm{~V}_{2} \mathrm{O}_{7}$ $\mathrm{Cu}_{2} \mathrm{~V}_{2} \mathrm{O}_{7}$ system, $\mathrm{Cu}_{1.6} \mathrm{Zn}_{0.4} \mathrm{~V}_{2} \mathrm{O}_{7}$ and $\mathrm{Cu}_{0.8} \mathrm{Zn}_{1.2} \mathrm{~V}_{2} \mathrm{O}_{7}$, were studied in a wide temperature range $\left(-180-400{ }^{\circ} \mathrm{C}\right)$ in order to determine the dependence of the non-autonomous phase appearance on the nature of thermal deformations of crystal lattice. The temperature dependencies of the unit cell parameters for $\mathrm{Cu}_{1.6} \mathrm{Zn}_{0.4} \mathrm{~V}_{2} \mathrm{O}_{7}$ and $\mathrm{Cu}_{0.8} \mathrm{Zn}_{1.2} \mathrm{~V}_{2} \mathrm{O}_{7}$ are shown in Fig. 4 . One can see that the values of unit cell parameters change monotonously within the studied temperature range. The $a$ parameter decreases significantly with temperature. The values of negative volume thermal expansion of the lattice for the both solid solutions correlate well with changes in the parameter $a$ (for $\mathrm{Cu}_{1.6} \mathrm{Zn}_{0.4} \mathrm{~V}_{2} \mathrm{O}_{7} \alpha_{V}$ $\left.=-3.14 \times 10^{-5} \mathrm{deg}^{-1}\right)$. The parameter $c$ and the monoclinic angle $\beta$ remain practically unchanged. It should be noted that the rotation angle of vanadium-oxygen tetrahedron $\mathrm{V}-\mathrm{O}_{\text {bridge }}-\mathrm{V}$ for the samples $\mathrm{Cu}_{1.6} \mathrm{Zn}_{0.4} \mathrm{~V}_{2} \mathrm{O}_{7}$ and $\mathrm{Cu}_{0.8} \mathrm{Zn}_{1.2} \mathrm{~V}_{2} \mathrm{O}_{7}$ at temperature $-180^{\circ} \mathrm{C}$ was equal to $131.6(8)^{\circ}$ and $129.9(7)^{\circ}$, respectively, and slightly decreased to $130.5(4)^{\circ}$ and $129.3(4)^{\circ}$, respectively, when temperature was raised to $400{ }^{\circ} \mathrm{C}$, since the structure belongs to the space group $C 2 / c$. Based on the obtained data, one can conclude that the absence of the non-autonomous phase in the $\mathrm{Zn}_{2} \mathrm{~V}_{2} \mathrm{O}_{7}-\mathrm{Cu}_{2} \mathrm{~V}_{2} \mathrm{O}_{7}$ system is due to the combined effect of two factors: insignificant shear deformations of the crystal lattice, governed by the change of the monoclinic angle $\beta$, and the mobility of vanadium-oxygen subsystem (Fig. 5) due to additional turn of vanadium-oxygen bi-ortogroups, 
since the angle of the $\mathrm{V}-\mathrm{O}_{\text {bridge }}-\mathrm{V}$ is not fixed by the symmetry rules.

A comparative crystal-chemical analysis of monoclinic solid solutions $\beta-\mathrm{Zn}_{2-2 x} \mathrm{Cd}_{2 x} \mathrm{~V}_{2} \mathrm{O}_{7}$ and $\beta-\mathrm{Cu}_{2-2 x} \mathrm{Zn}_{2 x} \mathrm{~V}_{2} \mathrm{O}_{7}$ showed that the shear deformations are more intensive for $\beta-\mathrm{Zn}_{2-2 x} \mathrm{Cd}_{2 x} \mathrm{~V}_{2} \mathrm{O}_{7}$ in the temperature range from the room temperature up to $600{ }^{\circ} \mathrm{C}\left(-1.2 \times 10^{-5} \mathrm{deg}^{-1}\right)$, which correlates with the appearance of the non-autonomous phase. In the case of $\beta-\mathrm{Cu}_{2-2 x} \mathrm{Zn}_{2 x} \mathrm{~V}_{2} \mathrm{O}_{7}\left(0.42 \times 10^{-5} \mathrm{deg}^{-1}\right)$, where shear deformations are absent, no non-autonomous phase was detected. Thus, the assumption that non-autonomous phase is generated by the shear deformations of the matrix phase due to a change in the monoclinic angle was confirmed.

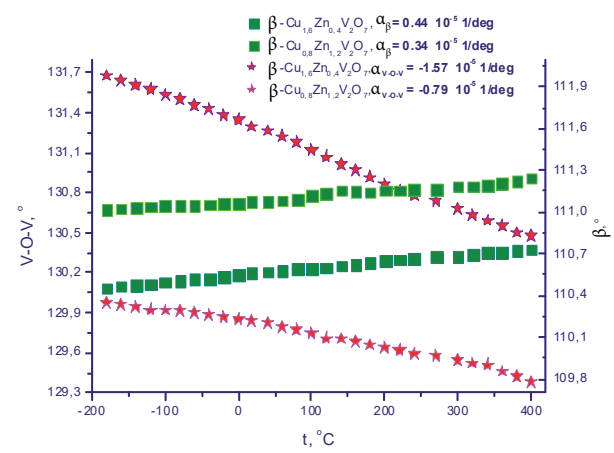

Fig. 5. The monoclinic angle and the rotation angle of $\left[\mathrm{VO}_{4}\right]$-tetrahedron in $\mathrm{Cu}_{2-2 x} \mathrm{Zn}_{2 x} \mathrm{~V}_{2} \mathrm{O}_{7}$ versus temperature

\section{Conclusion}

The set of in situ X-ray diffraction data and a comparative crystal-chemical analysis of zinc and copper pyrovanadates solid solutions that take into account thermal and chemical deformations of the structure allowed to established that the nonautonomous phase is formed when the following conditions are achieved: (1) the volume thermal expansion is close to zero; (2) shear deformations due to a change in the monoclinic angle appear (the degree of freedom that is not fixed by the sym- metry rules in the monoclinic crystals); (3) compounds belong to the space group $\mathrm{C} 2 / \mathrm{m}$ (mirror symmetry, the angle of $\mathrm{V}$ $\mathrm{O}_{\text {bridge }}-\mathrm{V}$ chain is $180^{\circ}$ ). The appearance of the non-autonomous phase under these conditions is a result of the matrix phase adaptation to the increase of inner-crystalline pressure that arises, while the unit cell volume remain unchanged, because of the shear deformation and a symmetry prohibition for the polyhedron architecture changes.

\section{Acknowledgements}

The work was supported by UB RAS (project 18-10-3-32).

\section{References}

1. Rossini FD, Prigogine I. Chemical Thermodynamics. Wiley; 1961. 514 p.

2. Defay R, Prigogine I, Bellemans A. Surface Tension and Absorption. London: Longmans, Green; 1966. 431 p.

3. Urusov VS, Tauson VL, Akimov VV. Geokhimiya tverdogo tela [Geochemistry of solid state]. Moscow: GEOS, 1997. 500 p. Russian.

4. Schegol'kov YuV, Tauson VL, Medvedev VYa, Pochekunina MV, Ivanova LA, Lipko SV. Vzaimodeystvie poverkhnosti elementnogo zolota s flyuidami - klyuch $\mathrm{k}$ ponimaniyu mekhanizmov perekondensatsii i mobilizatsii zolota $\mathrm{v}$ endogennykh i ekzogennykh usloviyakh. Doklady RAN. 2007;412(6):810-3. Russian. 
5. Lipko SV, Tauson VL, Akimov VV, Zel'berg BI, Knizhnik AV. Povedenie elementovprimesey v poroshkovom alyuminii [Behavior of elements-admixtures in powdered aluminium]. Tsvetnaya Metallurgiya [Non-ferrous Metallurgy]. 2006;4:13-9. Russian.

6. Tauson VL, Kravtsova RG, Smagunov NV, Spiridonov AM, Grebenschikova VI, Budyak AE. Strukturnoe i poverkhnostno-svyazannoe zoloto v piritakh mestorozhdeniy raznykh geneticheskikh tipov. Doklady RAN. 2006 ;406(6):806-9. Russian.

7. Tauson VL, Kravtsova RG, Smagunov NV, Spiridonov AM, Grebenshchikova VI, Budyak AE. Structurally and superficially bound gold in pyrite from deposits of different genetic types. Russian Geology and Geophysics. 2014;55(2):273-89. DOI:10.1016/j.rgg.2014.01.011

8. Tomashpolskiy YuYa. Poverkhnostnaya avtosegregatsiya v khimicheskikh soedineniyakh [Superficial auto-segregation in chemical compounds]. Moscow: Nauchnyy Mir, 2013. 208 p. Russian.

9. Pervov VS, Makhonina EV, Dobrokhotova ZhV, Dubasova VS, Zarvazhnov AYu. Supramolecular model of eutectics: Functional materials based on nonautonomous phases. Inorg Mater. 2009;45(12):1478-83. DOI:10.1134/S0020168509120140

10. Gusarov VV, Malkov AA, Malygin AA, Suvorov SA. Termicheski stimulirovannye transformatsii 2-mernykh neavtonomnykh faz i uplotnenie oksidnykh polikristallicheskikh materialov. Neorganicheskie materialy [Russ J Inorg Chem]. 1995;31(3):346-50. Russian.

11. Gusarov VV, Suvorov SA. Temperatura plavleniya lokal'no-ravnovesnykh poverkhnostnykh faz v polikristallicheskikh sistemakh na osnove odnoy ob'emnoy fazy [Melting temperatures of locally equilibrated surficial phases in polycrystallic systems based on the single phase]. Zhurnal prikladnoy khimii [Russ J Applied Chem]. 1990;63(8):1689-94. Russian.

12. Gusarov VV, Suvorov SA. Tolschina 2-mernykh neavtonomnykh faz v lokal'noravnovesnykh polikristallicheskikh sistemakh na osnove odnoy ob'emnoy fazy [Thickness of 2D non-autonomous phases in locally equilibrated polycrystallic systems based on the single phase]. Zhurnal prikladnoy khimii [Russ J Applied Chem]. 1993;66(7):1529-34. Russian.

13. Gusarov VV. The thermal effect of melting in polycrystalline systems. Thermochim Acta. 1995;256(2):467-72. DOI:10.1016/0040-6031(94)01993-Q

14. Gusarov VV. Statika i dinamika polikristallicheskikh system na osnove tugoplavkikh oksidov [dissertation]. [St. Petersburg]: 1996. Russian.

15. Uvarov NF, Boldyrev VV. Size effects in chemistry of heterogeneous systems. Russ Chem Rev. 2001;70(4):307-29. DOI:10.1070/RC2001v070n04ABEH000638

16. Pestereva NN, Neiman AYa. Reversibility of electrosurface transfer through eutectic interfaces of $\mathrm{MeWO}_{4} \mid \mathrm{WO}_{3}(\mathrm{Me}-\mathrm{Ca}, \mathrm{Sr}, \mathrm{Ba})$. Russ J Electrochem. 2012;48(11):1070-8. DOI:10.1134/S1023193512110134 